\title{
New mouse models for metabolic bone diseases generated by genome-wide ENU mutagenesis
}

\author{
Sibylle Sabrautzki • Isabel Rubio-Aliaga - Wolfgang Hans • Helmut Fuchs • \\ Birgit Rathkolb · Julia Calzada-Wack • Christian M. Cohrs • Matthias Klaften • \\ Hartwig Seedorf · Sebastian Eck • Ana Benet-Pagès · Jack Favor • \\ Irene Esposito - Tim M. Strom • Eckhard Wolf - Bettina Lorenz-Depiereux • \\ Martin Hrabě de Angelis
}

Received: 22 November 2011 / Accepted: 27 February 2012/Published online: 21 April 2012

(C) The Author(s) 2012. This article is published with open access at Springerlink.com

\begin{abstract}
Metabolic bone disorders arise as primary diseases or may be secondary due to a multitude of organ malfunctions. Animal models are required to understand the molecular mechanisms responsible for the imbalances of bone metabolism in disturbed bone mineralization diseases. Here we present the isolation of mutant mouse models for metabolic bone diseases by phenotyping blood parameters that target bone turnover within the large-scale genomewide Munich ENU Mutagenesis Project. A screening panel of three clinical parameters, also commonly used as biochemical markers in patients with metabolic bone diseases, was chosen. Total alkaline phosphatase activity and total
\end{abstract}

I. Rubio-Aliaga and W. Hans contributed equally to this study.

S. Sabrautzki - I. Rubio-Aliaga · W. Hans · H. Fuchs ·

C. M. Cohrs · M. Klaften - M. Hrabě de Angelis ( $\square)$

Institute of Experimental Genetics, Helmholtz Zentrum

München, German Research Center for Environmental Health

$(\mathrm{GmbH})$, Ingolstaedter Landstr. 1, 85764 Neuherberg, Germany

e-mail: hrabe@helmholtz-muenchen.de

B. Rathkolb · E. Wolf

Chair for Molecular Animal Breeding and Biotechnology,

Gene Center of the Ludwig-Maximilians-Universität München,

Ludwig-Maximilians-Universität München,

Feodor-Lynen-Str. 25, 81377 Munich, Germany

J. Calzada-Wack · I. Esposito

Institute of Pathology, Helmholtz Zentrum München,

German Research Center for Environmental Health $(\mathrm{GmbH})$,

Ingolstaedter Landstr. 1, 85764 Neuherberg, Germany

Present Address:

M. Klaften

Karlsruher Institut fuer Technologie, DE

Innovationsmanagement (IMA), Hermann-von-Helmholtz-Platz

1, 76344 Eggenstein-Leopoldshafen, Germany calcium and inorganic phosphate levels in plasma samples of F1 offspring produced from ENU-mutagenized $\mathrm{C} 3 \mathrm{HeB} /$ FeJ male mice were measured. Screening of 9,540 mice led to the identification of 257 phenodeviants of which 190 were tested by genetic confirmation crosses. Seventy-one new dominant mutant lines showing alterations of at least one of the biochemical parameters of interest were confirmed. Fifteen mutations among three genes (Phex, Casr, and Alpl) have been identified by positional-candidate gene approaches and one mutation of the Asgrl gene, which was identified by next-generation sequencing. All new mutant mouse lines are offered as a resource for the scientific community. 


\section{Introduction}

Metabolic bone diseases originate from endocrine dysfunctions as well as from heterogeneous determinants, including age, life style, and environmental influences. Bone turnover is physiologically regulated by hormones, cytokines, and growth factors and is under the control of numerous signaling pathways (Chavassieux et al. 2007). Metabolic diseases may have primary or secondary impact on bone mineralization. For investigating disease development and progression and to understand the underlying mechanisms, mice have been shown to serve successfully as model organisms (e.g., Abe et al. 2007; Kurima et al. 2002; Marklund et al. 2010; McGowan et al. 2008). Random $N$-ethyl- $N$-nitrosourea (ENU) mutagenesis is a promising approach to obtain mouse models for inherited human diseases (Hrabě de Angelis and Balling 1998). This has been shown in worldwide ENU mutagenesis programs, including bone metabolism, using dual-energy X-ray absorptiometry (DEXA), X-ray analysis, biochemical markers, or the SHIRPA protocol for the phenotyping of ENU mutagenesis-derived $\mathrm{C} 3 \mathrm{H} / \mathrm{HeJ}$, BALB/cCRLAnn, and B57BL/6 J mice (Barbaric et al. 2008; Smits et al. 2010; Srivastava et al. 2003).

Within the large-scale Munich ENU mutagenesis screen more than 850 mutant mouse lines have been isolated, derived from a large-scale genome-wide screen (Hrabě de
Angelis et al. 2000) or from an implemented modifier screen on Dll1 ${ }^{\text {lac } Z}$ knockout mice (Rubio-Aliaga et al. 2007). Our Dysmorphology Screen is focusing on the isolation of new mouse models for hereditary metabolic bone diseases (Fuchs et al. 2006; Lisse et al. 2008).

In previous studies in mice the reliability of biochemical markers for skeletal disorders, including alkaline phosphatase (ALP), has been shown (Srivastava et al. 2001). Combined ALP, total calcium $(\mathrm{Ca})$, and inorganic phosphate $\left(\mathrm{P}_{\mathrm{i}}\right)$ measurements in serum or plasma are routinely performed in patients with metabolic bone diseases (Table 1).

$\mathrm{Ca}$ and $\mathrm{P}_{\mathrm{i}}$ homeostasis is balanced by intestinal absorption, mobilization, or binding in bone and renal excretion. Ca levels directly and indirectly influence intestinal phosphate absorption. Much less is known about the influences on $\mathrm{P}_{\mathrm{i}}$ homeostasis (Bergwitz and Jüppner 2010). A key role in maintaining phosphate homeostasis is the reabsorption of phosphate from urine into the renal proximal tubules. A previously identified phosphaturic factor, FGF23 (fibroblast growth factor 23), acts as an endocrine hormone on the regulation of $\mathrm{P}_{\mathrm{i}}$ reabsorption in the kidney and on renal vitamin D metabolism (ADHR Consortium 2000; Strom and Jüppner 2008).

Here we describe the results of the Munich ENU Mutagenesis Project to obtain new mutant mouse models for impaired bone metabolism by phenotyping for alterations of at least one of the described plasma parameters as selection

Table 1 Mouse models for metabolic bone diseases with altered ALP activity and Ca and $\mathrm{P}_{\mathrm{i}}$ values in plasma and corresponding human diseases with equivalent changes

\begin{tabular}{|c|c|c|c|c|}
\hline Mouse models & *ALP & $\mathrm{Ca}$ & $\mathrm{P}_{\mathrm{i}}$ & Human disease \\
\hline${ }^{\mathrm{A}} \mathrm{Fgf23}{ }^{\mathrm{R} 176 \mathrm{Q}}$ & $\uparrow^{\mathrm{a}}$ & $\varnothing^{\mathrm{a}}$ & $\downarrow^{\mathrm{a}}$ & $\begin{array}{l}\text { Autosomal dominant hypophosphatemic } \\
\text { rickets (ADHR) }\end{array}$ \\
\hline${ }^{\mathrm{B}} \mathrm{Dmp} 1^{\mathrm{tm} 1.1 \mathrm{Mis}},{ }^{\mathrm{C}} \mathrm{DMP} 1^{\mathrm{tm} 1 \mathrm{Jqf}}$ & $\uparrow^{\mathrm{b}}$ & $\emptyset^{\mathrm{b}}$ & $\downarrow^{\mathrm{c}}$ & $\begin{array}{l}\text { Autosomal recessive hypophosphatemic } \\
\text { rickets (ARHR) }\end{array}$ \\
\hline${ }^{\mathrm{D}} \mathrm{Slc} 34 \mathrm{a} 3^{\mathrm{tm} 1 \mathrm{Kimi}}$ & $\uparrow^{\mathrm{d}, \mathrm{e}}$ & $\varnothing^{\mathrm{f}, \mathrm{g}}$ & $\downarrow^{\mathrm{e}, \mathrm{g}}$ & $\begin{array}{l}\text { Hereditary hypophosphatemic rickets } \\
\text { with hypercalciuria (HHRH) }\end{array}$ \\
\hline 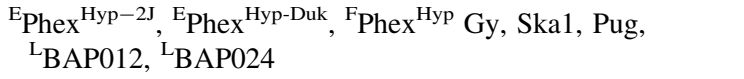 & $\uparrow \uparrow^{h}$ & $\varnothing$ & $\downarrow^{\mathrm{b}}$ & X-linked hypophosphatemic rickets (XLHR) \\
\hline $\begin{array}{l}{ }_{\mathrm{G}}^{\mathrm{G}} \mathrm{Alpl}^{\mathrm{Hpp}},{ }^{\mathrm{H}} \mathrm{Alpl}{ }^{\mathrm{tm} 1(\mathrm{cre}) \mathrm{Nagy}},{ }^{\mathrm{I}} \mathrm{Alpl}{ }^{\mathrm{tm} 1 \mathrm{Jlm}},{ }^{\mathrm{K}} \mathrm{Alpl}{ }^{\mathrm{tm} 1 \text { Sor }} \\
{ }^{\mathrm{L}} \mathrm{BAP} 020,{ }^{\mathrm{L}} \mathrm{BAP} 023,{ }^{\mathrm{L}} \mathrm{BAP} 026,{ }^{\mathrm{L}} \mathrm{BAP} 027,{ }^{\mathrm{L}} \mathrm{BAP} 032\end{array}$ & $\downarrow^{\mathrm{h}, \mathrm{i}}$ & $\uparrow^{\mathrm{k}}$ & $\varnothing-\uparrow^{\mathrm{k}}$ & Hypophosphatasia (HPP) \\
\hline e.g., ${ }^{\mathrm{M}} \mathrm{Col1a} 1{ }^{\mathrm{Aga} 2},{ }^{\mathrm{N}} \mathrm{Col} 1 \mathrm{a} 2{ }^{\text {oim }},{ }^{\mathrm{O}} \mathrm{Col} 1 \mathrm{a} 11^{\mathrm{Mov} 13},{ }^{\mathrm{P}} \mathrm{Col} 1 \mathrm{a} 1{ }^{\mathrm{Tm} 1 \mathrm{Jae}}$ & $\uparrow^{1, m}$ & $\varnothing$ & $\mathrm{n}$ & Osteogenesis imperfecta \\
\hline $\mathrm{Q}_{\mathrm{V} c p^{\mathrm{tm} 1 \mathrm{Ig} 1}}$ & $\uparrow \uparrow^{\mathrm{i}}$ & $\emptyset^{\mathrm{n}}-\uparrow^{\mathrm{o}}$ & $\varnothing^{p}$ & Paget's disease of bone (PDB) \\
\hline 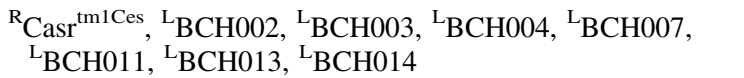 & $\varnothing$ & $\uparrow^{\mathrm{q}, \mathrm{r}}$ & $\downarrow^{\mathrm{q}, \mathrm{r}}$ & Primary hyperparathyroidism \\
\hline
\end{tabular}

$\emptyset$ unchanged, $\uparrow$ increased, $\downarrow$ decreased, $n$ no data, $A L P$ alkaline phosphatase, $C a$ total calcium, $P_{i}$ total inorganic phosphate

${ }^{a}$ Econs and McEnery (1997), ${ }^{b}$ Lorenz-Depiereux et al. (2006a), ${ }^{c}$ Lorenz-Depiereux et al. (2010), ${ }^{\mathrm{d}}$ Mejia-Gaviria et al. (2010), ${ }^{\mathrm{e}}$ LorenzDepiereux et al. (2006b), ${ }^{\mathrm{f}}$ Delmas (1992), ${ }^{\mathrm{g}}$ Tieder et al. (1985), ${ }^{\mathrm{h}}$ Mornet et al. (2001), ${ }^{\mathrm{i}}$ Whyte $(2010),{ }^{\mathrm{k}}$ Chodirker et al. (1990), ${ }^{\mathrm{l}} \mathrm{Cundy}$ et al. (2007), ${ }^{\mathrm{m}}$ Braga et al. (2004), ${ }^{\mathrm{n}}$ Singer et al. (1998), ${ }^{\mathrm{o}}$ Freeman (1988), ${ }^{\mathrm{p}}$ Goseki-Sone et al. (2005), ${ }^{\mathrm{q}}$ Bilezikian et al. (2005), ${ }^{\mathrm{r}}$ Tiosano and Hochberg (2009)

${ }^{A}$ Farrow et al. (2011), ${ }^{\mathrm{B}}$ Feng et al. (2008), ${ }^{\mathrm{C}}$ Feng et al. (2003), ${ }^{\mathrm{D}}$ Segawa et al. (2009), ${ }^{\mathrm{E}}$ Lorenz-Depiereux et al. (2004), ${ }^{\mathrm{F}}$ Eicher and Southard (1972), ${ }^{\mathrm{G}}$ Hough et al. (2007), ${ }^{\mathrm{H}}$ Lomeli et al. (2000), ${ }^{\mathrm{I}}$ Narisawa et al. (1997), ${ }^{\mathrm{K}}$ MacGregor et al. (1995), ${ }^{\mathrm{L}}$ Table 4 , ${ }^{\mathrm{M}}$ Lisse et al. (2008), ${ }^{\mathrm{N}}$ Chipman et al. (1993), ${ }^{\mathrm{O}}$ Bonadio et al. (1990), ${ }^{\mathrm{P}}$ Liu (1995), ${ }^{\mathrm{Q}}$ Badadani et al. (2010), ${ }^{\mathrm{R}} \mathrm{Ho}$ et al. (1995) 
markers. We isolated 71 new murine models that may be of special value for the development of new therapeutic approaches since a high number of metabolic bone diseases in human patients are caused by point mutations (Marini et al. 2010; Simon-Bouy et al. 2008; Wenkert et al. 2011).

\section{Material and methods}

Mice

For this study we used $\mathrm{C} 3 \mathrm{HeB} / \mathrm{FeJ}(\mathrm{C} 3 \mathrm{H})$ inbred mice purchased originally from the Jackson Laboratory (Bar Harbor, ME, USA) and bred in our animal facility. The mice were housed and handled according to the federal animal welfare guidelines and the state ethics committee approved all animal studies. The mice were kept in a 12/12-h dark-light cycle and provided standard chow ad libitum (TPT total pathogen-free chow \#1314: calcium content $0.9 \%$, phosphate $0.7 \%$, vitamin D3 600 IE; Altromin, Lage, Germany) and water. Hygienic monitoring was performed following FELASA recommendations (Nicklas et al. 2002). Mutant mouse lines derived from our screen were given internal lab codes and were assigned with official gene symbols and names after the mutation was identified.

\section{ENU mutagenesis}

ENU mutagenesis treatment of inbred strain $\mathrm{C} 3 \mathrm{H}$ males was as described previously (Aigner et al. 2011). Litters produced from the ENU-treated $\mathrm{C} 3 \mathrm{H}$ males (G0) are designated $\mathrm{F} 1$ in the following, while offspring produced from confirmed mutant F1 animals are designated G2.

Generation of F1 mice and confirmation of phenotypes in a dominant breeding strategy

The F1 animals investigated for this study were derived from a total of $893 \mathrm{G} 0$ males from 15 different ENUtreated groups. Blood samples of 9,540 F1 animals $(4,606$ females and 4,934 males) were screened for alterations of total ALP, Ca, and $\mathrm{P}_{\mathrm{i}}$ blood plasma levels. $\mathrm{F} 1$ mice showing alterations of blood-based parameters were retested after 14 days. Breeding for confirmation of a dominant phenotype was performed as described previously (Aigner et al. 2007).

Blood measurements

Blood samples $(250 \mu \mathrm{l})$ were obtained from 12-week-old nonfasted anesthetized mice by puncture of the retroorbital sinus, as already described (Rathkolb et al. 2000). All samples were collected between 9:00 and 11:00 a.m.
Plasma analysis of ALP, $\mathrm{Ca}$, and $\mathrm{P}_{\mathrm{i}}$ was done using an Olympus AU400 autoanalyzer (Olympus, Hamburg, Germany) and adapted test kits (Klempt et al. 2006). Descriptive data are expressed as mean \pm standard deviation. PTH values were analyzed with a Mouse Intact PTH ELISA Kit (TECOmedical, Bünde, Germany).

DXA and X-ray measurement

DXA (pDEXA Sabre, Norland Medical Systems Inc., Basingstoke, Hampshire UK, distributed by Stratec Medizintechnik GmbH, Pforzheim, Germany) and X-ray (Faxitron, Hewlett Packard, Palo Alto, CA, USA) measurements were performed for in-depth analysis in selected mouse lines as described previously (Abe et al. 2006; Fuchs et al. 2011).

\section{Genetic mapping}

To map the mutations, ENU-derived mutant mice were outcrossed to wild-type C57BL/6 J (B6) mice, as described previously (Aigner et al. 2009). For linkage analysis, SNP (single-nucleotide polymorphism) genotyping by highthroughput MALDI-TOF (matrix-assisted laser desorption/ ionization time-of-flight) technology supplied by Sequenom (San Diego, CA, USA) was performed with a panel containing 158 markers evenly distributed over the whole genome (Klaften and Hrabě de Angelis 2005). We developed the internal MyGenotype database for statistical SNP data analysis.

\section{Mutation analysis}

Casr, Phex, Alpl, and Asgrl exons were amplified with intronic primers and directly sequenced using BigDye v3.1 cycle sequencing (Applied Biosystems, Life Technologies, Foster City, CA, USA). Casr consists of 7 exons (NM013803), Phex (NM011077) consists of 22 exons, and Alpl (NM007431) consists of 12 exons. All primer sequences are available upon request. The mutation of the BAP005 mutant line was detected by chromosome sorting (CHROMBIOS, Raubling, Germany) and whole-chromosome sequencing on a Genome Analyzer IIx (Illumina, San Diego, CA, USA). DNA extraction from sorted chromosomes 11 was performed overnight at $42{ }^{\circ} \mathrm{C}$ with $0.25 \mathrm{M}$ EDTA, $10 \%$ Na lauroyl sarcosine, and $50 \mu \mathrm{g}$ proteinase $\mathrm{K}$. Extracted DNA was precipitated and resuspended in TE buffer. Paired-end libraries were constructed with the Illumina paired-end DNA sample preparation kit according to the manufacturer's protocols and as described previously (Eck et al. 2009). Alignment of the reads was performed with the BWA software, and subsequent analysis was performed with the SAMtools package. In total, $\sim 82$ million reads and $\sim 157$ million reads were generated for the mutant and control strain, respectively, of which $64 \%$ mapped to the 
target chromosome 11 for the mutant strain, while $26 \%$ of the control strain reads were on target. The identified nonsynonymous sequence variation in Asgrl was confirmed in mutant mice by capillary sequencing.

\section{Statistical analysis}

Statistical analysis of parameters of F1 animals and sexand age-matched wild-type $\mathrm{C} 3 \mathrm{H}$ mice were performed using the software package JMP Release 5.1 (SAS Institute, Cary, NC, USA). The reference values were obtained from untreated age-matched $\mathrm{C} 3 \mathrm{H}$ wild-type control groups (50 males and 50 females). Single F1 variants for ALP activity and Ca levels were defined by a $Z$ score $\geq 3$ or $\leq-3$ compared to the age-matched control groups. Mice showing hypophosphatemia were tested three times to confirm $P_{i}$ changes. A $Z$ score of $\leq-2$ was taken to select variants for hypophosphatemia. Statistical differences ( $P$ values) of the means of ALP, $\mathrm{Ca}$, or $\mathrm{P}_{\mathrm{i}}$ blood values between all tested affected mice and nonaffected littermates of a mutant line were assessed by one-way analysis of variance (ANOVA), $t$ test (giving mean $\pm \mathrm{SD}$ values), and the Mann-Whitney rank sum test (giving median values) using SigmaStat 3.5 (Systat Software Inc., Chicago, IL, USA).

\section{Results}

Overall results and statistics

In order to identify early stages of disturbed bone turnover, we investigated the diagnostic value of routine assays for
ALP activity and $\mathrm{Ca}$ and $\mathrm{P}_{\mathrm{i}}$ levels in the plasma of mice derived from ENU-treated males for its comparability to their use in human patients (Table 1). This table also shows other mouse lines obtained for selected metabolic bone diseases and the observed alterations of plasma parameters in these models. Since we were interested only in mouse lines showing alterations of the bone ALP (bALP) isoform of the measured total ALP enzyme, variants with additional alterations of ALAT (alanine-amino-transferase) and ASAT (aspartate-amino-transferase) levels were excluded from this study.

Two hundred fifty-seven phenodeviants $(2.7 \%, 87$ females and 170 males) of 9,540 F1 animals showed alterations in at least one of the three parameters of interest (ALP, $\mathrm{Ca}$, and $\mathrm{P}_{\mathrm{i}}$ ) in two repeated blood measurements. One hundred ninety of the 257 (74\%) phenodeviants were mated to wild-type $\mathrm{C} 3 \mathrm{H}$ mice in confirmation crosses. In 71 of the mated 190 (37\%) (25 females and 46 males), the observed phenotype was genetically transmitted as a dominant trait (Table 2); however, six of these mutant lines were lost because no mutant male offspring was produced for sperm cryopreservation. For 110 of the mated 190 (58 \%) phenodeviants, inheritance could not be confirmed because of sterility $(n=22 / 110,20 \%)$, the mice died due to unknown reasons $(n=15 / 110,14 \%)$, or the hypothesis of a dominant mutation was excluded $(n=73 / 110,66 \%)$. Confirmation crosses for the remaining 9 of the 190 phenodeviants are still underway. Sixty-seven of the 257 (26\%) phenodeviants were not mated due to space limitations; however, their sperm was frozen. Founder F1 mice with a similar phenotype and derived from the identical G0 male were expected to carry the identical mutation. Fifteen mutations have been
Table 2 Genetic confirmation crosses and confirmed mutations for F1 variants with alterations of ALP activity and/ or $\mathrm{Ca}$ and $\mathrm{P}_{\mathrm{i}}$ plasma values $\uparrow$ high, $\downarrow$ low, $\varnothing$ unchanged, $A L P$ alkaline phosphatase, $C a$ total calcium, $P_{i}$ total inorganic phosphate

\begin{tabular}{|c|c|c|c|c|c|}
\hline \multicolumn{3}{|c|}{ Phenotype $^{\mathrm{a}}$} & \multicolumn{3}{|c|}{ Confirmation crosses } \\
\hline ALP & $\mathrm{Ca}$ & $P_{i}$ & Total number & $\begin{array}{l}\text { Confirmed (\% of total F1 tested } \\
\text { for this phenotype) }\end{array}$ & Ongoing \\
\hline$\uparrow$ & $\varnothing$ & $\varnothing$ & 83 & 28 (33.7) & 1 \\
\hline$\uparrow$ & $\uparrow$ & $\varnothing$ & 4 & $2(50)$ & 0 \\
\hline$\uparrow$ & $\uparrow$ & $\uparrow$ & 1 & 0 & 0 \\
\hline$\uparrow$ & $\uparrow$ & $\downarrow$ & 1 & $1(100)$ & 0 \\
\hline$\uparrow$ & $\downarrow$ & $\varnothing$ & 1 & $1(100)$ & 0 \\
\hline$\uparrow$ & $\varnothing$ & $\downarrow$ & 14 & $4(28.6)$ & 1 \\
\hline$\downarrow$ & $\varnothing$ & $\varnothing$ & 10 & $6(60)$ & 1 \\
\hline$\downarrow$ & $\varnothing$ & $\downarrow$ & 1 & 0 & 0 \\
\hline$\varnothing$ & $\uparrow$ & $\varnothing$ & 20 & $9(45)$ & 0 \\
\hline$\varnothing$ & $\uparrow$ & $\uparrow$ & 1 & 0 & 0 \\
\hline$\varnothing$ & $\uparrow$ & $\downarrow$ & 8 & $4(50)$ & 2 \\
\hline$\varnothing$ & $\downarrow$ & $\varnothing$ & 3 & $1(33)$ & 0 \\
\hline$\varnothing$ & $\varnothing$ & $\uparrow$ & 2 & $1(50)$ & 0 \\
\hline$\varnothing$ & $\varnothing$ & $\downarrow$ & 41 & $14(34.1)$ & 4 \\
\hline Total & & & 190 & 71 (37.4) & 9 \\
\hline
\end{tabular}


identified resulting in new alleles of the Phex, Casr, and Alpl genes (Table 3).

New mouse lines carrying mutations of the Phex (phosphate-regulating gene with homologies to endopeptidases on the $\mathrm{X}$-chromosome) gene

Affected animals of the BAP012 (Bone screen Alkaline Phosphatase No. 012) mutant line displayed a significant $(P \leq 0.001)$ decrease in plasma $\mathrm{P}_{\mathrm{i}}$ levels. Female mutant mice $(n=42)$ exhibited a $\mathrm{P}_{\mathrm{i}}$ value of $1.3 \pm 0.2 \mathrm{mmol} / \mathrm{l}$ compared to female wild-type mice $(2.0 \pm 0.3 \mathrm{mmol} / \mathrm{l}$, $n=11)$. Male mutant mice $(n=7)$ had a $\mathrm{P}_{\mathrm{i}}$ value of $1.2 \pm 0.1 \mathrm{mmol} / 1 \mathrm{compared}$ to $2.0 \pm 0.3 \mathrm{mmol} / 1$ in male wild-type mice $(n=44)$. Mean ALP activity was significantly elevated $(P \leq 0.001)$ in female mutants $(266.4 \pm$ $35.3 \mathrm{U} / \mathrm{l})$ compared to wild-type littermates (147.9 \pm 17.9 $\mathrm{U} / \mathrm{l})$, and also in mutant male mice $(370.9 \pm 88.5 \mathrm{U} / \mathrm{l})$ compared to their wild-type littermates $(120 \pm 8.5 \mathrm{U} / \mathrm{l})$. In addition to these biochemical alterations, all mutants showed reduced body size, shortened hind limbs, and mild head-tossing behavior as described in other Phex mouse models (Lorenz-Depiereux et al. 2004; Moriyama et al. 2011). Genetic crosses revealed $X$-linked inheritance of the phenotype. Thus, mutant mice of both sexes were derived from mated mutant females, but from matings of male mutants only female mutants were born. Based on the phenotypic data, the causative mutation was hypothesized to be in the Phex gene. DNA sequence analysis of the Phex gene revealed a new hemizygous nonsense mutation in exon 2 (c.148A $>$ T, p.Lys50X) (Fig. 1a). The mutation is located within the large extracellular domain of the protein close to the transmembrane domain. The Phex gene in mice is syntenic to the human $P H E X$ gene, which is organized into 22 exons and encodes a type II transmembrane protein with homology to zinc metallopeptidases (HYP Consortium 1995). Inactivating mutations of the PHEX gene cause X-linked dominant hypophosphatemic rickets (XLHR), which has an incidence of 1:20,000 and is the most common familial form of hypophosphatemic rickets in humans (Burnett et al. 1964; Tenenhouse 1999).

Mice of the BAP024 mutant line express similar phenotypes, with gender influences on inheritance as the $\mathrm{C} 3 \mathrm{Heb} / \mathrm{FeJ}-\mathrm{Ph} \mathrm{x}^{\mathrm{BAP012}}$ mice. In BAP024 we found a new missense mutation in exon 22 of the Phex gene (c.2197T > C, p.Cys733Arg) (Fig. 1b), also located in the large extracellular catalytic domain of the protein. The cysteine at position 733 is highly conserved among other vertebrate species (Du et al. 1996). A cysteine-to-serine substitution at the corresponding position of the $\mathrm{C} 3 \mathrm{Heb} /$ FeJ-Phex ${ }^{\text {BAP024 }}$ mutation has been described recently in a patient with XLHR (Filisetti et al. 1999). No spontaneous
Phex point mutations on the $\mathrm{C} 3 \mathrm{H}$ strain have been isolated previously.

New mouse lines carrying mutations of the Casr (calcium-sensing receptor) gene

The BCH002 (Bone screen Calcium High No. 002) line showed a statistically significant increase of $\mathrm{Ca}$ levels in mutant animals compared to wild-type littermates $(P \leq$ 0.001). Female mutants' Ca level was $2.9 \pm 0.1 \mathrm{mmol} / \mathrm{l}$ ( $n=23$ ) compared to $2.43 \pm 0.1 \mathrm{mmol} / \mathrm{l}$ for wild-type littermates $(n=19)$. The male mutant value was $2.87 \pm 0.1 \mathrm{mmol} / \mathrm{l}(n=20)$ compared to the wild-type littermates' value of $2.41 \pm 0.1 \mathrm{mmol} / \mathrm{l}(n=20)$. Fiftythree percent of female and male mutant BCH002 mice had slightly reduced $\mathrm{P}_{\mathrm{i}}$ levels. Histological analysis showed enlarged parathyroid glands in heterozygous mutant mice (Fig. 2a). A group of 11 female (6 mutants, 5 wild types) and 20 male mice (10 mutants, 10 wild types) was tested for PTH values, resulting in significantly raised median PTH values for mutant mice $(P \leq 0.001)$ : female mutants, $214.9 \mathrm{pg} / \mathrm{ml}(25 \% 203.3 \mathrm{pg} / \mathrm{ml}$ and $75 \% 265.7 \mathrm{pg} / \mathrm{ml})$, and wild types, $85.7 \mathrm{pg} / \mathrm{ml}(25 \% 79.6 \mathrm{pg} / \mathrm{ml}$ and $75 \%$ $113.1 \mathrm{pg} / \mathrm{ml})$. Male mutants showed $235 \mathrm{pg} / \mathrm{ml}(25 \%$ $191 \mathrm{pg} / \mathrm{ml}$ and $75 \% 409.9 \mathrm{pg} / \mathrm{ml}$ ) compared to wild types showing $102.7 \mathrm{pg} / \mathrm{ml} \quad(25 \% \quad 78.8 \mathrm{pg} / \mathrm{ml}$ and $75 \%$ $117.2 \mathrm{pg} / \mathrm{ml}$ ). So far eight pups were derived from a first heterozygous intercross but no homozygous mutant was found. Mapping analysis of 40 mutant and 20 wild-type $\mathrm{BCH} 002$ animals derived from the dominant backcrosses to the B6 strain revealed linkage to chromosome 16 (Table 4), with the highest $\chi^{2}$ value at the marker rs4186801 (51.47 Mb, mouse genome Build 37.1, UCSC). In this region Casr was the most promising candidate gene for the observed phenotype. DNA sequence analysis of the Casr gene revealed a new heterozygous missense mutation (c.2579T > A, p. Ile859Asn) within the protein-coding region of exon 7 (Fig. 2b) of the gene that was not present in wild-type $\mathrm{C} 3 \mathrm{H}$ and $\mathrm{B} 6$ mice. CASR belongs to the family of G-protein-coupled receptors (GPCRs) and is an integral membrane protein that senses changes in the extracellular calcium concentration to parathyroid cells.

In addition, six new alleles of the Casr gene were isolated in other mouse lines (BCH003, BCH004, BCH007, $\mathrm{BCH011,} \mathrm{BCH013,} \mathrm{and} \mathrm{BCH014)} \mathrm{(Table} \mathrm{3)} \mathrm{creating} \mathrm{an}$ allelic series for functional analysis of the gene. Median PTH levels were significantly increased $(P=0.010)$ in first testings of $\mathrm{BCH} 013$ female mutants $(n=6)$, showing $175.2 \mathrm{pg} / \mathrm{ml}(25 \% 143.21 \mathrm{pg} / \mathrm{ml}$ and $75 \% 198.33 \mathrm{pg} / \mathrm{ml})$ compared to wild types $(n=4)$ showing $50.061 \mathrm{pg} / \mathrm{ml}$ (25\% $48.805 \mathrm{pg} / \mathrm{ml}$ and $75 \% \quad 56.962 \mathrm{pg} / \mathrm{ml}$ ). Male mutants $(n=10)$ displayed $100.984 \pm 30.765 \mathrm{pg} / \mathrm{ml}$ and wild types $(n=9) 55.485 \pm 14.734 \mathrm{pg} / \mathrm{ml}$. For all other 
Table 3 Confirmed mutant mouse lines with alterations of ALP activity and Ca and $\mathrm{P}_{\mathrm{i}}$ plasma values

\begin{tabular}{|c|c|c|c|}
\hline $\begin{array}{l}\text { Line } \\
\text { name }\end{array}$ & Variant phenotype & Additional phenotype, comment & $\begin{array}{l}\text { Transmissior } \\
(\%)^{\mathrm{a}}\end{array}$ \\
\hline BAP001 & High ALP & & $<20$ \\
\hline BAP002 & High ALP, high Ca & $\begin{array}{l}\text { All variants with brittle teeth, jaw abnormality ( } \sim 3 \text { months old); changes in the tubular } \\
\text { bone structure, reduced bone density }\end{array}$ & 64 \\
\hline BAP003 & High ALP, high Ca & $\begin{array}{l}\text { Mapped on Chr } 4 \text { between SNP markers rs } 28307021 \text { and rs3711383 (101.16-141.90 Mb, } \\
\text { mouse genome Build 37.1, UCSC) }\end{array}$ & 62 \\
\hline BAP004 & $\begin{array}{l}\text { High ALP and/or high } \\
\text { Ca and/or low } \mathrm{P}_{\mathrm{i}}\end{array}$ & $\begin{array}{l}\text { All variants with auricle degeneration when }>4 \text { months old; reduced body size; mapped } \\
\text { on Chr } 4 \text { between SNP markers rs } 28056583 \text { and rs13469808 (86.81-117.55 Mb, } \\
\text { mouse genome Build 37.1, UCSC) }\end{array}$ & 75 \\
\hline BAP005 & High ALP & Mutation of the Asgrl (asialoglycoprotein receptor 1) gene, c.815A > G; p.Tyr272Cys & 92 \\
\hline BAP006 & High ALP & Identical G0 as BAP007 & lost \\
\hline BAP007 & High ALP & Identical G0 as BAP006; counted with BAP006 as one line & lost \\
\hline BAP008 & High ALP & Identical G0 as BPL001 & 71 \\
\hline BAP009 & High ALP & All variants show circling behavior, reduced body size & 32 \\
\hline BAP010 & High ALP & & lost \\
\hline BAP011 & High ALP & & 32 \\
\hline BAP012 & High ALP, low $P_{i}$ & $\begin{array}{l}\text { All variants small with shortened hind limbs, circling behavior. Nonsense mutation in } \\
\text { exon } 2 \text { of the Phex (phosphate-regulating gene with homologies to endopeptidases on } \\
\text { the X chromosome) gene, c.148A > T; p.Lys50X }\end{array}$ & 100 \\
\hline BAP013 & High ALP & & 27 \\
\hline BAP014 & High ALP & $\begin{array}{l}\text { Significantly more males born and affected; offspring of heterozygous intercrosses with } \\
\text { reduced body size, ALP very high; mapped on Chr } 9 \text { between SNP markers rs3023207 } \\
\text { and rs3673055 (37.50-96.23 Mb, mouse genome Build 37.1, UCSC) }\end{array}$ & 60 \\
\hline BAP015 & High ALP & & lost \\
\hline BAP016 & High ALP & & 70 \\
\hline BAP017 & High ALP & All variants with reduced body size & $<20$ \\
\hline BAP018 & High ALP & & 96 \\
\hline BAP019 & High ALP & & 29 \\
\hline BAP020 & Low ALP & $\begin{array}{l}\text { Synonymous sequence variation in exon } 10 \text { of the } \mathrm{Alpl} \text { (alkaline phosphatase, liver/bone/ } \\
\text { kidney) gene, c.1098A }>\mathrm{T} \text {, p.Thr365Thr }\end{array}$ & 100 \\
\hline BAP021 & High ALP & High ALAT and ASAT, phenotype probably liver dependent & 44 \\
\hline BAP022 & High ALP & & 100 \\
\hline BAP023 & Low ALP & $\begin{array}{l}\text { Missense mutation in exon } 7 \text { of the } \mathrm{Alpl} \text { (alkaline phosphatase, liver/bone/kidney) gene, } \\
\text { c.755T > G; p.Leu251Pro. Identical G0 animal as BAP021 and BCH009 }\end{array}$ & 100 \\
\hline BAP024 & High ALP, low $P_{i}$ & $\begin{array}{l}\text { All variants with reduced body size, circling behavior. Missense mutation in exon } 22 \text { of } \\
\text { the Phex (phosphate-regulating gene with homologies to endopeptidases on the } \mathrm{X} \\
\text { chromosome) gene, c. } 2197 \mathrm{~T}>\mathrm{C} \text {; p.Cys733Arg }\end{array}$ & 100 \\
\hline BAP025 & High ALP & & 100 \\
\hline BAP026 & Low ALP & $\begin{array}{l}\text { Splice site mutation in intron } 9 \text { of the } A l p l \text { gene (alkaline phosphatase, liver/bone/kidney) } \\
\text { gene c. } 997+2 \mathrm{~T}>\mathrm{G}\end{array}$ & 85 \\
\hline BAP027 & Low ALP & $\begin{array}{l}\text { Missense mutation in exon } 10 \text { of the Alpl (alkaline phosphatase, liver/bone/kidney) gene, } \\
\text { c.1194T > A, p.Ile395Asn }\end{array}$ & 100 \\
\hline BAP028 & High ALP & All mutants with reduced body size & 100 \\
\hline BAP029 & High ALP & & 30 \\
\hline BAP030 & High ALP & All mutants with reduced body size & 56 \\
\hline BAP031 & High ALP & & 52 \\
\hline BAP032 & Low ALP & $\begin{array}{l}\text { Missense mutation in exon } 11 \text { of the Alpl (alkaline phosphatase, liver/bone/kidney) gene, } \\
\text { c. } 1217 \mathrm{~A}>\mathrm{G} \text {, p.Asp406Gly }\end{array}$ & 90 \\
\hline ВCH001 & High $\mathrm{Ca}$ & & $<20$ \\
\hline ВCH002 & High $\mathrm{Ca}$, low $\mathrm{P}_{\mathrm{i}}$ & $\begin{array}{l}\text { Missense mutation in exon } 7 \text { of the } \operatorname{Casr} \text { (calcium-sensing receptor) gene, c.2579T }>\text { A; } \\
\text { p.Ile859Asn. Some intercrosses derived offspring with reduced body size, gray fur }\end{array}$ & 100 \\
\hline
\end{tabular}


Table 3 continued

\begin{tabular}{|c|c|c|c|}
\hline $\begin{array}{l}\text { Line } \\
\text { name }\end{array}$ & Variant phenotype & Additional phenotype, comment & $\begin{array}{l}\text { Transmission } \\
(\%)^{\mathrm{a}}\end{array}$ \\
\hline ВCH003 & High $\mathrm{Ca}$ & $\begin{array}{l}\text { Missense mutation in exon } 3 \text { of the Casr (calcium-sensing receptor) gene, c. } 295 \mathrm{G}>\mathrm{T} \text {, } \\
\text { p.Asp99Tyr. Identical G0 as BCH006 }\end{array}$ & 100 \\
\hline BCH004 & High Ca & $\begin{array}{l}\text { Nonsense mutation in exon } 4 \text { of the Casr (calcium-sensing receptor) gene, c. } 366 \mathrm{G}>\mathrm{T} \text {, } \\
\text { p.Glu } 456 \mathrm{X}\end{array}$ & 93 \\
\hline BCH005 & High $\mathrm{Ca}$ & & 22 \\
\hline BCH006 & High $\mathrm{Ca}$ & Identical G0 as $\mathrm{BCH} 003$; counted with $\mathrm{BCH} 003$ as a single line & 100 \\
\hline BCH007 & High Ca & $\begin{array}{l}\text { Missense mutation in exon } 4 \text { of the Casr (calcium-sensing receptor) gene, c.626T }>\text { C; } \\
\text { p.Val208Ala. Some intercrosses derived offspring show reduced body size. }\end{array}$ & 74 \\
\hline ВCH008 & High Ca & & 78 \\
\hline ВCH009 & High $\mathrm{Ca}$ & Identical G0 animal as BAP021 and BAP023 & $<20$ \\
\hline BCH010 & High Ca & & 20 \\
\hline BCH011 & High Ca & $\begin{array}{l}\text { Nonsense mutation in exon } 7 \text { of the Casr (calcium-sensing receptor) gene, c. } 2017 \mathrm{C}>\mathrm{T} \text {, } \\
\text { p.Gln673X }\end{array}$ & 100 \\
\hline $\mathrm{BCH} 012$ & High Ca & & $<20$ \\
\hline $\mathrm{BCH} 013$ & High Ca & $\begin{array}{l}\text { Missense mutation in exon } 3 \text { of the Casr (calcium-sensing receptor) gene, c.296A > G, } \\
\text { p.Asp99Gly }\end{array}$ & 100 \\
\hline BCL001 & Low Ca, high ALP & & 100 \\
\hline BCL002 & Low $\mathrm{Ca}$ & & 50 \\
\hline BPH001 & High $\mathrm{P}_{\mathrm{i}}$ & & lost \\
\hline BPL001 & Low $\mathrm{P}_{\mathrm{i}}$ & Identical G0 animal as BAP008 & $<20$ \\
\hline BPL002 & Low $\mathrm{P}_{\mathrm{i}}$ & $\begin{array}{l}\text { Mapped on Chr } 16 \text { between SNP markers rs4186801 and rs4199268 (51.47-69.80 Mb, } \\
\text { mouse genome Build 37.1, UCSC) }\end{array}$ & 38 \\
\hline BPL003 & Low $\mathrm{P}_{\mathrm{i}}$ & & $<20$ \\
\hline BPL004 & Low $\mathrm{P}_{\mathrm{i}}$ & $\begin{array}{l}\text { Mapped on Chr } 3 \text { between SNP markers rs13477178 and rs13477321 (69.55-109.00 Mb, } \\
\text { mouse genome Build 37.1, UCSC) }\end{array}$ & 63 \\
\hline BPL005 & Low $\mathrm{P}_{\mathrm{i}}$ & & 46 \\
\hline BPL006 & Low $\mathrm{P}_{\mathrm{i}}$ & $\begin{array}{l}\text { All mutants with reduced body size; mapped on Chr } 14 \text { between SNP markers } \\
\text { rs30406796 and rs30865397 ( } 22.92-74.08 \mathrm{Mb} \text {, mouse genome Build 37.1, UCSC) }\end{array}$ & 73 \\
\hline BPL007 & Low $\mathrm{P}_{\mathrm{i}}$ & All mutants with reduced body size & 53 \\
\hline BPL008 & Low $\mathrm{P}_{\mathrm{i}}$ & $\begin{array}{l}\text { All mutants with reduced body size; mapped on Chr } 8 \text { between SNP markers rs } 13479952 \\
\text { and rs13479998 (103.43-116.69 Mb, mouse genome Build 37.1, UCSC) }\end{array}$ & 37 \\
\hline BPL009 & Low $\mathrm{P}_{\mathrm{i}}$ & & 40 \\
\hline BPL010 & Low $\mathrm{P}_{\mathrm{i}}$ & & 100 \\
\hline BPL011 & Low $\mathrm{P}_{\mathrm{i}}$ & & 67 \\
\hline BPL012 & Low $\mathrm{P}_{\mathrm{i}}$ & & 50 \\
\hline BPL013 & Low $\mathrm{P}_{\mathrm{i}}$ & & 50 \\
\hline BPL014 & Low $\mathrm{P}_{\mathrm{i}}$ & & 100 \\
\hline SAP003 & High ALP & & $<20$ \\
\hline SAP004 & Low $\mathrm{Ca}$, low $\mathrm{P}_{\mathrm{i}}$ & & $<20$ \\
\hline SAP005 & High ALP & & lost \\
\hline SAP006 & High ALP & & 41 \\
\hline SAP007 & Low ALP & $\begin{array}{l}\text { Missense mutation in exon } 12 \text { of the } \mathrm{Alpl} \text { (alkaline phosphatase, liver/bone/kidney) gene, } \\
\text { c.1357A > G; p.Thr453Ala }\end{array}$ & 100 \\
\hline SAP008 & High ALP & & 62 \\
\hline SCA001 & High $\mathrm{Ca}$ & & 49 \\
\hline SMA010 & High ALP, high Ca & All variants with reduced body size $(Z$ score $<-2)$ & 31 \\
\hline TRE002 & High ALP & All mutants trembling, high ALP probably secondary effect & 100 \\
\hline
\end{tabular}

All mouse lines listed in alphabetical order of the internal lab names

a According to dominant inheritance $50 \%$ mutant offspring corresponds to $100 \%$ transmission of the phenotype 
A

BAP012: Phex exon 2 c.148A>T, p.Lys50X
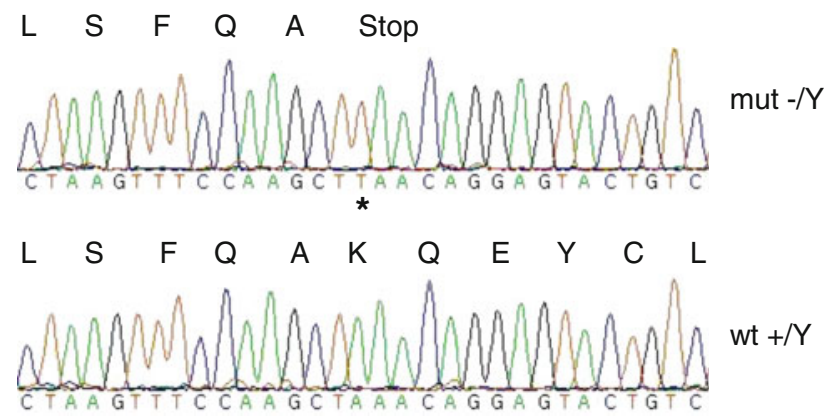

B

BAP024: Phex exon 22 c.2197T>C, p.Cys733Arg
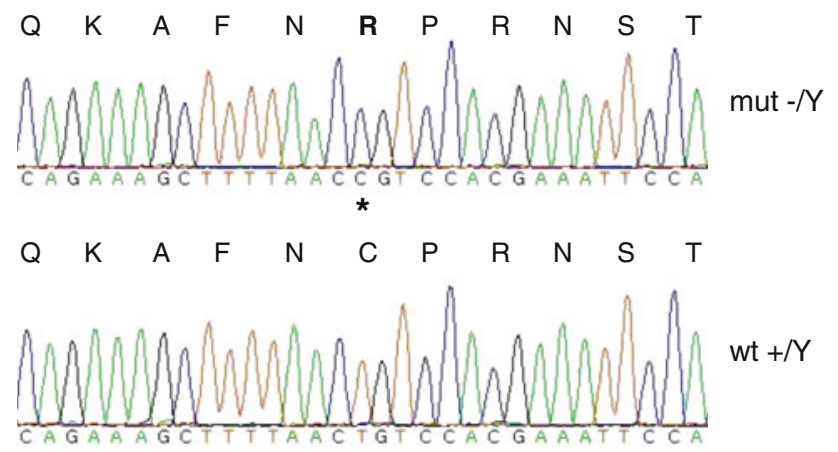

Fig. 1 a DNA sequence analysis of the Phex gene exon 2 revealed a hemizygous nonsense mutation (c.148A > T, p.Lys50X) in the DNA of a male $\mathrm{C} 3 \mathrm{Heb} / \mathrm{FeJ}-\mathrm{Phex}{ }^{\mathrm{BAP012}}$ mutant mouse leading to a premature translation stop codon after 49 amino acids. b DNA sequence analysis of the Phex gene exon 22 revealed a hemizygous missense mutation (c.2197T > C, p.Cys733Arg) in the DNA of a male $\mathrm{C} 3 \mathrm{Heb} / \mathrm{FeJ}-\mathrm{Phex}{ }^{\mathrm{BAP} 024}$ mutant mouse. Variants are marked by an asterisk

mouse lines with mutations of the Casr gene, PTH data are underway. The missense and nonsense mutations of these mouse lines were located in exons 3, 4, 5, and 7 of the Casr gene (Table 3).

New mouse lines carrying mutations of the Alpl

(alkaline phosphatase, liver/bone/kidney) gene

In mutant mice of the BAP032 line, statistically significant $(P<0.001)$ low mean ALP activity was found in female mutants (47 $\pm 5.8 \mathrm{U} / 1, n=9)$ compared to wild-type littermates $(157.8 \pm 7.9 \mathrm{U} / 1, n=8)$, and in male mutants (38.4 $\pm 6.3 \mathrm{U} / 1, n=12$ ) compared to wild-type littermates (129.5 $\pm 10.1 \mathrm{U} / \mathrm{l}, n=10)$ (Fig. 3a). Significantly reduced ALP activity suggested a mutation in the Alpl gene encoding the tissue nonspecific ALP (TNSALP). We sequenced this gene in BAP032 mice and revealed a new heterozygous missense mutation in exon 11 located within the protein-coding region of the $\mathrm{Alpl}$ gene on chromosome 4 (c.1217A > G, p.Asp406Gly) (Fig. 3b). This mutation was not found in wild-type $\mathrm{C} 3 \mathrm{H}$ littermates or in wild-type B6 mice. We isolated five additional mouse lines carrying new alleles of the Alpl gene (Table 3). Four sequence variations were located in exons 7,10 , or 12 (BAP020, BAP023, BAP027, SAP007) and one affects the splice site in intron 9 (BAP026).

Other mouse lines and mutations

Female and male mutant mice of the BAP005 line showed statistically significant $(P \leq 0.001)$ increased mean ALP activity. The value in female mutants $(n=25)$ was $233 \pm 21 \mathrm{U} / 1$ compared to $136 \pm 14 \mathrm{U} / 1$ in wild-type littermates $(n=32)$, and in male mutants $(n=39)$ ALP activity was $188 \pm 19.81 \mathrm{U} / \mathrm{l}$ compared to $104.5 \pm 10.43$ $\mathrm{U} / \mathrm{l}$ in their wild-type littermates $(n=36)$. The mouse line breeds homozygous offspring with very high ALP activities. Homozygous females derived from heterozygous intercrosses showed mean ALP activity of $587 \pm 39$ U/l $(n=12)$, and ALP activity in homozygous males was $482 \pm 51 \mathrm{U} / 1(n=21)$. SNP mapping revealed a region between the markers rs26982471 and rs27000576 (53.99-114.33 Mb, mouse genome Build 37.1, UCSC) on chromosome 11. Sorting of chromosome 11 and whole chromosome 11 sequencing on a GAIIx next-generation sequencing machine revealed a new missense mutation in the Asgrl (asialoglykoprotein receptor 1) gene within the translated region (c.815A > G, p.Tyr272Cys). The mutation was sequenced in 16 BAP005 mutant mice, but neither in 4 wild-type littermates, nor in additional 4 wild-type mice from different inbred strains (BALB/c, DBA/2, FVB, SJL).

For eight additional mouse lines (BAP002, BAP003, BAP004, BAP014, BPL004, BPL006, BPL008, and TRE002) showing high ALP activity, low $\mathrm{P}_{\mathrm{i}}$, and high or low $\mathrm{Ca}$ values as a phenotype, genetic mapping has been finished (Table 3) and sequencing of candidate genes is in progress. For selected mouse lines we will include exome sequencing to find the causative mutation.

\section{Discussion}

In this study we described a large-scale ENU mutagenesis screen (Soewarto et al. 2009), with the main focus on malfunctioning bone turnover. In other projects murine models for disturbed bone metabolism were obtained by gene targeting (Daroszewska et al. 2011; Ducy et al. 1996; Forlino et al. 1999; Kato et al. 2002), transgene insertions (Imanishi et al. 2001; Rauch et al. 2010) or spontaneous mutations (Eicher et al. 1976; Marks and Lane 1976). Here, we isolated 71 new mouse models by screening for 
Fig. 2 a Representative pictures of the histological changes found in the mutant mouse line BCH002: 1, 2 (left) depict a $\mathrm{H} \& \mathrm{E}$-stained section of normal thyroid gland $(\mathrm{T})$ and parathyroid gland $(\mathrm{P})$ in a control mouse. In 1 (lowmagnification panel, $5 \times$, scale bar $=100 \mu \mathrm{m}$ ), the normal gland appears as a small compact mass of dark cells. In 2 at higher magnification $(20 \times$, scale bar $=20 \mu \mathrm{m}$ ), two cell types interspersed with capillaries and sinusoids are identified: the chief cells, with a small basophilic cytoplasm, and the light cells, with abundant light cytoplasm. 3, 4 (right) show a H\&E-stained section of the normal thyroid gland (T) and the enlarged parathyroid gland $(\mathrm{P})$ with loose structure observed in heterozygous $\mathrm{C} 3 \mathrm{HeB} / \mathrm{FeJ}-\mathrm{Casr}^{\mathrm{BCH} 002}$ mutant mice (3). At higher magnification in $\mathbf{4}$, an increase in the number of light cells is observed. b DNA sequence analysis of the Casr gene of $\mathrm{C} 3 \mathrm{HeB} / \mathrm{FeJ}-\mathrm{Casr}^{\mathrm{BCHOO2}}$ mice revealed a heterozygous mutation in exon 7 (c.2579T > A, p.Ile859Asn) that is marked by an asterisk
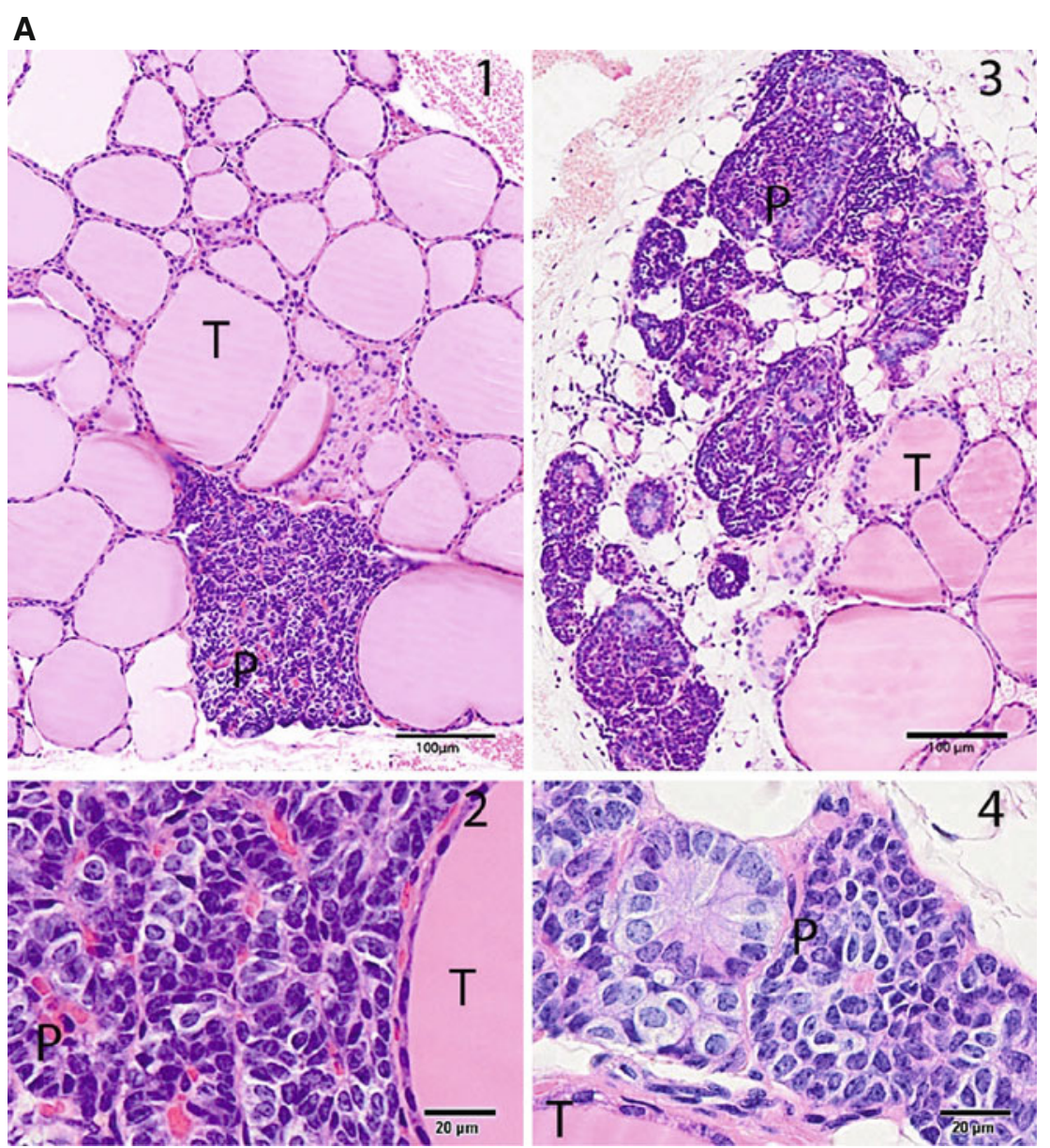

B

BCH002: Casr exon 7 c.2579T>A, p.lle860Asn
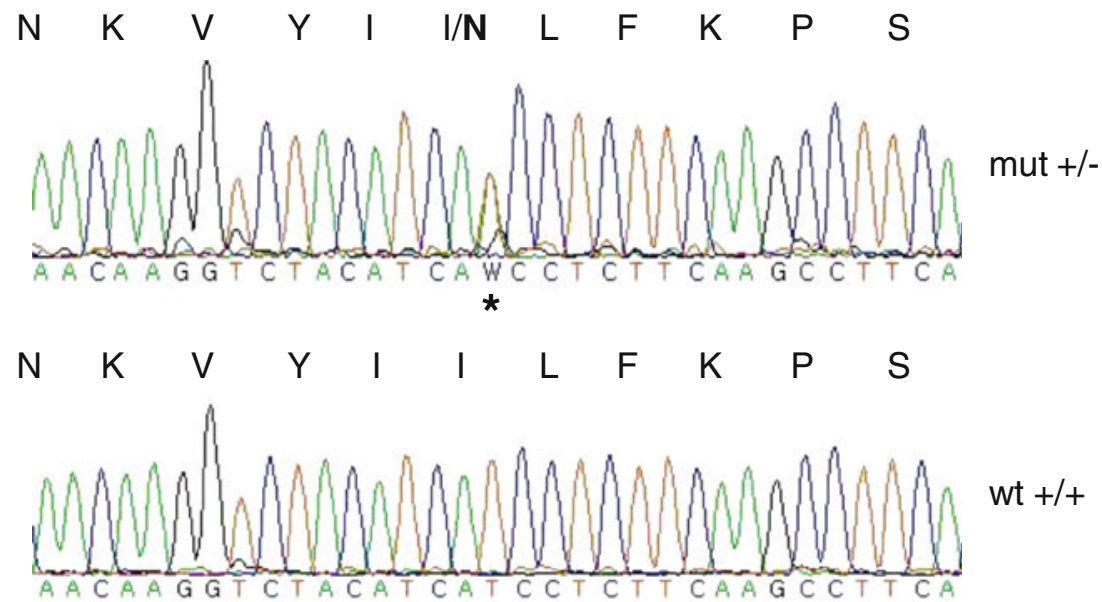

alterations of total ALP activity and total $\mathrm{Ca}$ and $\mathrm{P}_{\mathrm{i}}$ values in plasma of 9,540 F1 mice. Our results demonstrate that malfunctions of bone metabolism in mice may be efficiently detected by the analysis of human standard clinical chemical parameters.
In this study the highest fraction of new mouse lines revealed alterations of total ALP activity (Table 3). Since these mouse lines discriminated in phenotype expression and occurrence of additional phenotypes, the phenotypes presumably depend on different molecular mechanisms. 
Table 4 Statistical analysis of SNP mapping data of the C3HeB/FeJ$\mathrm{Casr}^{\mathrm{BCH} 002}$ mutant line obtained by MyGenotype database

\begin{tabular}{lll}
\hline Chromosome (marker) & Highest $\chi^{2}$ & Highest -log10(P) \\
\hline 1 (rs31593281) & 5.57 & 1.74 \\
2 (rs3691120) & 1,80 & 0.75 \\
3 (rs3685081) & 1.72 & 0.72 \\
4 (rs28307021) & 0.78 & 0.42 \\
5 (rs32067291) & 3.60 & 1.24 \\
6 (rs13478606) & 3.76 & 1.28 \\
7 (rs13479476) & 1.09 & 0.53 \\
8 (rs13479998) & 8.02 & 2.34 \\
9 (rs3023207) & 5.00 & 1.60 \\
$10(\mathrm{rs} 13480484)$ & 4.45 & 1.46 \\
11 (rs27000576) & 9.38 & 2.66 \\
12 (rs6194112) & 7.36 & 2.18 \\
13 (rs29566800) & 4.45 & 1.46 \\
14 (rs30482696) & 2.17 & 0.85 \\
15 (rs13482484) & 9.38 & 2.66 \\
16 (rs4186801) & 28.17 & 6.96 \\
17 (rs13483097) & 4.79 & 1.54 \\
18 (rs13483484) & 0.82 & 0.44 \\
19 (rs6339594) & 2.69 & 1.00 \\
\hline
\end{tabular}

Total ALP was chosen as a parameter of interest since elevated ALP activity is the most frequently measured parameter for human Paget's disease (Langston and Ralston 2004), X-linked hypophosphatemic rickets (XLHR) (Jonsson et al. 2003; Mäkitie et al. 2003), autosomal dominant hypophosphatemic rickets (ADHR) (Econs and McEnery 1997; Imel et al. 2007; Kruse et al. 2001), and type I osteoporosis (Avbersek-Luznik et al. 2007; Pedrazzoni et al. 1996).

Screening for alterations of total $\mathrm{Ca}$ and $\mathrm{P}_{\mathrm{i}}$ values without changes of ALP activity resulted in 34 mutant lines with confirmation of the observed phenotype (Table 2). While the $\mathrm{Ca}$ parameter was easy to measure, $\mathrm{P}_{\mathrm{i}}$ values were artificially elevated after plasma storage for longer than 1 day, freezing of the samples, or hemolysis. Metabolic bone diseases may be reflected in changes of more than one parameter, and very often two or three of the parameters of interest showed alterations in the same individual mouse line, as is commonly observed in human patients (Table 1).

In our screen we obtained new mouse models for hypophosphatemia, hyperparathyroidism, and hypophosphatasia. Despite the large number of existing mouse models for XLHR, there are still open questions on the mechanism of PHEX in renal phosphate wasting, abnormal vitamin D metabolism, and matrix mineralization (Addison et al. 2010; Brownstein et al. 2010). The C3HeB/FeJ$\mathrm{Phex}^{\mathrm{BAP} 012}$ and $\mathrm{C} 3 \mathrm{HeB} / \mathrm{FeJ}-\mathrm{Phex}^{\mathrm{BAP} 024}$ mutant lines

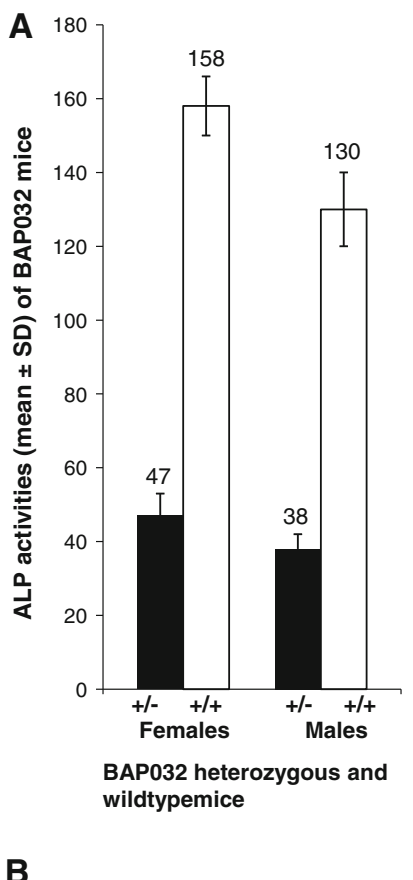

BAP032: Alp/ exon 11 c.1217A>G, p.Asp406Gly

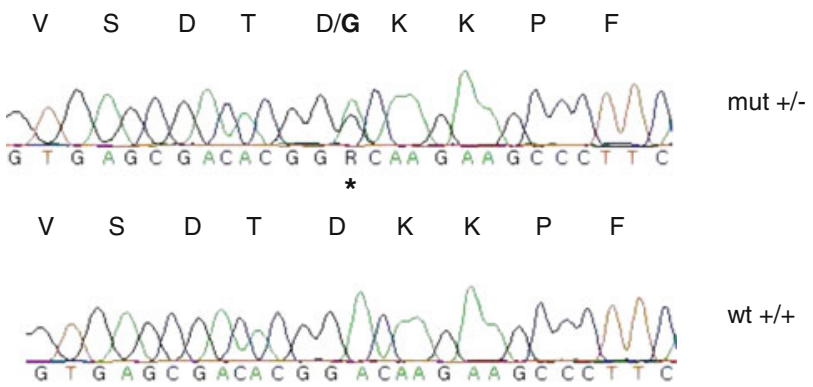

Fig. 3 a $\mathrm{C} 3 \mathrm{HeB} / \mathrm{FeJ}-\mathrm{Alpl}^{\mathrm{BAP} 032}$ ALP blood activities (mean $\pm \mathrm{SD}$ $\mathrm{U} / \mathrm{l})$ in female mutant $(N=8)$, female wild-type $(N=9)$, male mutant $(N=12)$, and male wild-type $(N=10)$ mice. Mean $\pm \mathrm{SD}$ ALP activities were: female mutants $47 \pm 5.8 \mathrm{U} / 1 \quad(P<0.001)$; female wild-types $157.8 \pm 7.9 \mathrm{U} / 1$; male mutants $38.4 \pm 6.3 \mathrm{U} / 1$ $(P<0.001)$; male wild-types $129.5 \pm 10.1 \mathrm{U} / 1$ ( $t$-test). b DNA sequence analysis of the Alpl gene exon 11 revealed a new heterozygous missense mutation (c.1217A > G, p.Asp406Gly). Variant is marked by an asterisk

represent two new mutant mouse lines with novel point mutations modeling XLHR in addition to previously published models (Carpinelli et al. 2002; Lorenz-Depiereux et al. 2004; Xiong et al. 2008).

New point mutations of the Casr gene were found in seven mouse lines. The large extracellular domain of the receptor contains clusters of amino acid residues, which may be involved in calcium binding (Brown et al. 1993). Exon 7 encodes the seven transmembrane domains and four intracellular loops of CASR (Chang et al. 2008). Human CASR mutations are known to be causative for primary hyperparathyroidism (HP) (Bilezikian et al. 2005) and familial benign hypocalciuric hypercalcemia (FHH) 
(Pollak et al. 1994). Approximately two thirds of FHH patients showed loss-of-function mutations involving the 3,234-bp coding region of the CASR gene (D'Souza-Li et al. 2002). Individuals with HP and FHH discriminate in creatinine clearance and serum magnesium values, both being higher in FHH (Marx et al. 1981). It has been demonstrated that individuals with FHH are heterozygous, and children within these families with severe neonatal primary hyperparathyroidism (NSHPT) are homozygous for CASR mutations (Janicic et al. 1995; Pollak et al. 1993). Mice with tissue-specific deletion of Casr in the parathyroid gland and bone exhibited profound bone defects (Chang et al. 2008). C3H;102 $\mathrm{Casr}^{\mathrm{Nuf}} / \mathrm{H}$ mice carry an activating ENU-derived Casr point mutation that exhibits hypocalcemia, hyperphosphatemia, cataracts, and ectopic calcifications (Hough et al. 2004). We obtained the first presumed loss-of-function point mutation isolated in $\mathrm{C} 3 \mathrm{HeB} / \mathrm{FeJ}-\mathrm{Casr}{ }^{\mathrm{BCH} 002}$ mice that is supposed to model human FHH. Since the mouse line has been bred more than 15 generations and because we found six other independent Casr mutations for this phenotype, it is more than likely that the consistent phenotype is due to the isolated point mutation of the Casr gene. Heterozygous $\mathrm{C} 3 \mathrm{HeB} / \mathrm{FeJ}-$ $\mathrm{Casr}^{\mathrm{BCH} 002}$ mice exhibited high $\mathrm{Ca}$ and $\mathrm{PTH}$ values similar to targeted Black Swiss/129SvJ Casr ${ }^{+/-}$and $\mathrm{Casr}^{-/-}$mice (Ho et al. 1995), but, in addition, they showed enlarged parathyroid glands described only for $\mathrm{Casr}^{-1-}$ mice. Further heterozygous intercrosses are required to find out if homozygous $\mathrm{C} 3 \mathrm{HeB} / \mathrm{FeJ}-\mathrm{Casr}^{\mathrm{BCH} 002}$ mice are viable, which is not the case in $\mathrm{Casr}^{-1-}$ mice. This would raise the opportunity to obtain a mouse model for NSHPT. More than 270 mutations have been described so far in the human CASR mutation database (www.casrdb.mcgill.ca; Nakajima et al. 2009), and interestingly most of the human mutations were found in exons 4 and 7. The mouse lines carrying Casr mutations obtained in our screen showed slight differences in the expression of the phenotype. Additional studies on phenotypical and histological traits will help to discriminate between the different effects of each point mutation on the severity of hyperparathyroidism and concomitantly to improve our understanding of $C A S R$ mutations in human patients.

Heterozygous $\mathrm{C} 3 \mathrm{HeB} / \mathrm{FeJ}-\mathrm{Alpl}^{\mathrm{BAP} 032}$ mice showed a statistically significant reduction of ALP activity in plasma without additional phenotypes, as observed in heterozygous $A k p 2^{H p p /+}$ mice derived in an ENU mutagenesis screen on $\mathrm{C} 3 \mathrm{H} / \mathrm{HeH}$ background (Hough et al. 2007). In Akp2 $2^{H p p /+}$ mice, an Alpl loss-of-function mutation led to the rare disease hypophosphatasia (HPP) which displays reduction of plasma ALP activities to about $50 \%$ in $A k p 2^{H p p /+}$ and a stronger reduction in $A k p 2^{H p p / H p p}$ mice. Akp2 $2^{H p p /+}$ mice were radiographically and histologically indistinguishable from wild-type mice at different time points, as were 16-week-old $\mathrm{C} 3 \mathrm{HeB} / \mathrm{FeJ}-\mathrm{Alpl}^{\mathrm{BAP} 032}$ mice in DEXA and $\mathrm{X}$-ray analysis. Interestingly, we observed a stronger ALP reduction in heterozygous $\mathrm{C} 3 \mathrm{HeB} / \mathrm{FeJ}-\mathrm{Alpl}^{\mathrm{BAP} 032}$ mice than in $A k p 2^{H p p /+}$ mice, with ALP activities in female and male mutant mice reduced to $29 \%$ of that found in wild-type littermates. Severe HPP forms are characterized by hypomineralization, rickets, seizures, and nephrocalcinosis due to hypercalciuria (Beck et al. 2009). Alpl $^{-/-}$mice showed a reduction in body size, no detectable ALP levels, and lethality prior to weaning, whereas $A l p l^{+/-}$mice appeared healthy (Narisawa et al. 1997). The identical point mutation of $\mathrm{C} 3 \mathrm{HeB} / \mathrm{FeJ}-\mathrm{Alpl}{ }^{\mathrm{BAP} 032}$ mice has also been described for a patient with HPP (Taillandier et al. 2000). Heterozygous $\mathrm{C} 3 \mathrm{HeB} / \mathrm{FeJ}-\mathrm{Alpl}^{\mathrm{BAP} 032}$ mice presumably model mild adult HPP. The mouse line was bred for more than ten generations, showing full penetrance of the phenotype in all litters. A multitude of diverse point mutations, deletions, and insertions of the human TNSALP gene causing HPP are listed in the hypophosphatasia database (www.sesep.uvsq.fr/03 hypo_mutations.php). The diversity of published human point mutations emphasizes the importance of mouse models for further investigations on physiological functions and cellular mechanisms of $\mathrm{Alpl}$ regions involved in collagen and $\mathrm{Ca}$ binding. Interestingly, we isolated in addition one silent mutation in the BAP020 mouse line (Table 4) showing the expected phenotype. No additional Alpl mutations were found in this mouse line. Alpl mRNA and translation of ALP were not analyzed so far.

Since only total ALP can be tested in mice so far, we probably will isolate mouse lines showing alterations other than the bone ALP isoform. High alterations of plasma ALP activities without any additional phenotypes, as observed in homozygous animals of the $\mathrm{C} 3 \mathrm{HeB} / \mathrm{FeJ}-$ Asgr $1^{\text {BAP005 }}$ line, have not been published in mice before. It has been described in patients with chronic liver disease that the adult intestinal ALP isoenzyme was increased due to the reduced efficiency or numbers of asialoglycoprotein receptors (Moss 1994). Thus, the mutation of the gene in BAP005 mice seems to cause alterations of the intestinal ALP isoform as a secondary effect. ASRG1 mutations may be responsible for high ALP activities of so far unknown reasons in humans without any skeletal disorders (Panteghini 1991) or may cause benign familial hyperphosphatasemia (Siraganian et al. 1989).

We have to consider bone as an active metabolic organ with a possible influence on metabolism in diseases of disturbed bone turnover (Ferron et al. 2010; Fulzele et al. 2010). For this reason, systematic analysis of all organ systems, as in the German Mouse Clinic (Gailus-Durner et al. 2005), might provide new insights into the actions in these pathways. Our mouse models will be archived by the European Mouse Mutant Archive (EMMA) and are available (www.emmanet.org) for the scientific community. 
Acknowledgments We thank Sandra Hoffmann, Andreas Mayer, Tommy Fuchs, Silvia Crowley, Annemieke Looienga, Elfi Holupirek, Jacqueline Mueller, Eleonore Samson, Sandy Lösecke, and Gerlinde Bergter for excellent technical assistance. We also thank Leticia Quintanella-Fendt for analysis of histologic images and Michael Roseman for scientific discussions. This work was supported by Nationales Genomforschungsnetz (NGFN 01GR0430), NGFNplus grants from the Bundesministerium für Bildung und Forschung (BMBF), (01GS0850 and 01GS0851), and BMBF OSTEOPATH grants (01EC1006B). The work was further supported by EU ANABONOS (LSH-2002-2.1.4-3) grants to MHdA.

Open Access This article is distributed under the terms of the Creative Commons Attribution License which permits any use, distribution, and reproduction in any medium, provided the original author(s) and the source are credited.

\section{References}

Abe K, Fuchs H, Lisse T, Hans W, de Angelis Hrabě (2006) New ENU-induced semidominant mutation, Ali18, causes inflammatory arthritis, dermatitis, and osteoporosis in the mouse. Mamm Genome 17:915-926

Abe K, Wechs S, Kalaydjiev S, Franz T, Busch DH (2007) Novel lymphocyte-independent mechanisms to initiate inflammatory arthritis via bone marrow derived cells of Ali18 mutant mice. Rheumatology 47(3):292-300

Addison WN, Masica DL, Gray JJ, McKee MD (2010) Phosphorylation-dependent inhibition of mineralization by osteopontin ASARM peptides is regulated by PHEX cleavage. J Bone Miner Res 25(4):695-705

ADHR Consortium (2000) Autosomal dominant hypophosphatemic rickets is associated with mutations in FGF23. Nat Genet 26(3):345-348

Aigner B, Rathkolb B, Mohr M, Klempt M, Hrabě de Angelis M et al (2007) Generation of ENU-induced mouse mutants with hypocholesterolemia: novel tools for dissecting plasma lipoprotein homeostasis. Lipids 42(8):731-737

Aigner B, Rathkolb B, Klaften M, Sedlmeier R, Klempt M et al (2009) Generation of N-ethyl-N-nitrosourea-induced mouse mutants with deviations in plasma enzyme activities as novel organ-specific disease models. Exp Physiol 94(4):412-421

Aigner B, Rathkolb B, Klempt M, Wagner S, Michel D et al (2011) Generation of N-ethyl-N-nitrosourea-induced mouse mutants with deviations in hematological parameters. Mamm Genome 22:495-505

Ashwell G, Morell AG (1974) The role of surface carbohydrates in the hepatic recognition and transport of circulating glycoproteins. Adv Enzymol Relat Areas Mol Biol 41:99-128

Avbersek-Luznik I, Gmeiner-Stopar T, Marc J (2007) Activity or mass concentration of bone-specific alkaline phosphatase as a marker of bone formation. Clin Chem Lab Med 45(8):10141018

Badadani M, Nalbandian A, Watts GD, Vesa J, Kitazawa M (2010) VCP associated inclusion body myopathy and Paget disease of bone knock-in mouse model exhibits tissue pathology typical of human disease. PLoS One 5(10):e13183

Barbaric I, Perry MJ, Dear TN, Rodrigues Da Costa A, Salopek D (2008) An ENU-induced mutation in the Ankrd11 gene results in an osteopenia-like phenotype in the mouse mutant Yoda. Physiol Genomics 32(3):311-321

Beck L, Karaplis AC, Amizuka N, Hewson AS, Ozawa H (1998) Targeted inactivation of $\mathrm{Npt} 2$ in mice leads to severe renal phosphate wasting, hypercalciuria, and skeletal abnormalities. Proc Natl Acad Sci USA 95(9):5372-5377

Beck C, Morbach H, Richl P, Stenzel M, Girschick HJ (2009) How can calcium pyrophosphate crystals induce inflammation in hypophosphatasia or chronic inflammatory joint diseases? Rheumatol Int 29(3):229-238

Bergwitz C, Jüppner H (2010) Regulation of phosphate homeostasis by PTH, vitamin D, and FGF23. Annu Rev Med 61:91-104

Bilezikian JP, Brandi ML, Rubin M, Silverberg SJ (2005) Primary hyperparathyroidism: new concepts in clinical, densitometric and biochemical features. J Int Med 257(1):6-17

Bonadio J, Saunders TL, Tsai E, Goldstein SA, Morris-Winmann J et al (1990) Transgenic mouse model of the mild dominant form of osteogenesis imperfecta. Proc Natl Acad Sci USA 87: $7145-7149$

Braga V, Gatti D, Rossini M, Colapietro F, Battaglia E (2004) Bone turnover markers in patients with osteogenesis imperfecta. Bone 34(6):1013-1016

Brown EM, Gamba G, Riccardi D, Lombardi M, Butters R et al (1993) Cloning and characterization of an extracellular $\mathrm{Ca}\left(2^{+}\right)$sensing receptor from bovine parathyroid. Nature 366:575-580

Brownstein CA, Zhang J, Stillman A, Elis B, Troiano N et al (2010) Increased bone volume and correction of Hyp mouse hypophosphatemia in the Klotho/Hyp mouse. Endocrinology 151(2):492-501

Burnett CH, Dent CE, Harper C, Warland BJ (1964) Vitamin D-resistant rickets. Am J Med 36:222-232

Carpinelli MR, Wicks IP, Sims NA, O’Donnell K, Hanzinikolas K et al (2002) An ethyl-nitrosourea-induced point mutation in Phex causes exon skipping, X-linked hypophosphatemia, and rickets. Am J Pathol 161(5):1925-1933

Chang W, Tu C, Chen TH, Bikle D, Shoback D (2008) The extracellular calcium-sensing receptor $(\mathrm{CaDR})$ is a critical modulator of skeletal development. Sci Signal 1(35):ra1

Chavassieux P, Seeman E, Delmas PD (2007) Insights into material and structural basis of bone fragility from diseases associated with fractures: how determinants of the biomechanical properties of bone are compromised by disease. Endocr Rev 28:151-164

Chipman SD, Sweet HO, McBride DJ Jr, Davisson MT, Marks SC Jr (1993) Defective pro alpha 2(I) collagen synthesis in a recessive mutation in mice: a model of human osteogenesis imperfecta. Proc Natl Acad Sci USA 90(5):1701-1705

Chodirker BN, Evans JA, Seargeant LE, Cheang MS, Greenberg CR (1990) Hyperphosphatemia in infantile hypophosphatasia: implications for carrier diagnosis and screening. Am J Hum Genet 46:280-285

Cundy T, Horne A, Bolland M, Gamble G, Davidson J (2007) Bone formation markers in adults with mild osteogenesis imperfecta. Clin Chem 53(6):1109-1114

D’Souza-Li, Yang B, Canaff L, Bai M, Hanley DA et al (2002) Identification and functional characterization of novel calciumsensing receptor mutations in familial hypocalciuric hypercalcemia and autosomal dominant hypocalcemia. J Clin Endocrinol Metab 87:1309-1318

Daroszewska A, van' t Hof RJ, Rojas JA, Layfield R, LandaoBasonga $E$ et al (2011) A point mutation in the ubiquitin associated domain of SQSMT1 is sufficient to cause a Paget's disease like disorder in mice. Hum Mol Genet 20(14):2734-2744

Delmas PD (1992) Clinical use of biochemical markers of bone remodeling in osteoporosis. Bone 13(Suppl 1):S17-S21

Du L, Desbarats M, Viel J, Glorieux FH, Cawthorn C et al (1996) cDNA cloning of the murine Phex gene implicated in X-linked hypophosphatemia and evidence for expression in bone. Genomics 36:22-28

Ducy P, Desbois C, Boyce B, Pinero G, Story B et al (1996) Increased bone formation in osteocalcin-deficient mice. Nature 382(6590): $448-452$ 
Eck SH, Benet-Pagès A, Flisikowski K, Meitinger T, Fries R et al (2009) Whole genome sequencing of a single Bos taurus animal for single nucleotide polymorphism discovery. Genome Biol 10(8):R82

Econs MJ, McEnery PT (1997) Autosomal dominant hypophosphatemic rickets/osteomalacia: clinical characterization of a novel renal phosphate-wasting disorder. J Clin Endocrinol Metab 82(2):674-681

Eicher EM, Southard JL (1972) Hypophosphatemia (Hyp); Chr 7 linkage. Mouse News Lett 47:36

Eicher EM, Southard JL, Scriver CR, Glorieux FH (1976) Hypophosphatemia: mouse model for human familial hypophosphatemic (vitamin D-resistant) rickets. Proc Natl Acad Sci USA 73:4667-4671

Farrow EG, Yu X, Summers LJ, Davis SI, Fleet JC et al (2011) Iron deficiency drives an autosomal dominant hypophosphatemic rickets (ADHR) phenotype in fibroblast growth factor-23 (Fgf23) knock-in mice. Proc Natl Acad Sci USA 108(46):E1146-E1155

Feng JQ, Huang H, Lu Y, Ye L, Xie Y et al (2003) The Dentin matrix protein 1 (Dmp1) is specifically expressed in mineralized, but not soft, tissues during development. J Dent Res 82(10):776-780

Feng JQ, Scott G, Guo D, Jiang B, Harris M et al (2008) Generation of a conditional null allele for Dmp1 in mouse. Genesis 46(2):87-91

Ferron M, Wei J, Yoshizawa T, Del Fattore A, DePinho RA et al (2010) Insulin signaling in osteoblasts integrates bone remodeling and energy metabolism. Cell 142(2):296-308

Filisetti D, Ostermann G, von Bredow M, Strom T, Filler G et al (1999) Non-random distribution of mutations in the PHEX gene, and under-detected missense mutations at non-conserved residues. Eur J Hum Genet 7(5):615-619

Forlino A, Porter FD, Lee EJ, Westphal H, Marini JC (1999) Use of the Cre/lox recombination system to develop a non-lethal knockin murine model for osteogenesis imperfecta with an $\alpha 1(\mathrm{I}) \mathrm{G} 349 \mathrm{C}$ substitution. J Biol Chem 274(53):37923-37931

Freeman DA (1988) Paget's disease of bone. Am J Med Sci 295(2):144-158

Fuchs H, Lisse T, Abe K, Hrabě de Angelis M (2006) Screening for bone and cartilage phenotypes in mice. In: Hrabě de Angelis M, Chambon P, Brown S (eds) Phenotyping of the laboratory mouse. Wiley-VCH, Weinheim, pp 35-86

Fuchs H, Gailus-Durner V, Adler T, Aguilar-Pimentel A, Becker L et al (2011) Mouse phenotyping. Methods 53(2):120-135

Fulzele K, Riddle RC, DiGirolamo D, Cao X, Wan C et al (2010) Insulin receptor signaling in osteoblasts regulates postnatal bone acquisition and body composition. Cell 142(2):309-319

Gailus-Durner V, Fuchs H, Becker L, Bolle I, Brielmeier M et al (2005) Introducing the German mouse clinic: open access platform for standardized phenotyping. Nat Methods 2(6):403-404

Goseki-Sone M, Sogabe N, Fukushi-Irie M, Mizoi L, Orimo H et al (2005) Functional analysis of the single nucleotide polymorphism $(787 \mathrm{~T}>\mathrm{C})$ in the tissue-nonspecific alkaline phosphatase gene associated with BMD. J Bone Miner Res 20(5):773-782

Ho C, Conner DA, Pollak MR, Ladd DJ, Kifor O et al (1995) A mouse model of human familial hypocalciuric hypercalcemia and neonatal severe hyperparathyroidism. Nat Genet 11(4):389-394

Hough TA, Bogani D, Cheeseman MT, Favor J, Nesbit MA et al (2004) Activating calcium-sensing receptor mutation in the mouse is associated with cataracts and ectopic calcification. Proc Natl Acad Sci USA 101(37):13566-13571

Hough TA, Polewski M, Johnson K, Cheeseman M, Nolan PM et al (2007) Novel mouse model of autosomal semidominant adult hypophosphatasia has a splice site mutation in the tissue nonspecific alkaline phosphatase gene akp2. J Bone Miner Res 22(9):1397-1407
Hrabě de Angelis M, Balling R (1998) Lange scale ENU screens in the mouse: genetics meets genomics. Mutat Res 400(1-2): $25-32$

Hrabě de Angelis M, Flaswinkel H, Fuchs H, Rathkolb B, Soewarto D et al (2000) Genome-wide, large-scale production of mutant mice by ENU mutagenesis. Nat Genet 25(4):444-447

HYP Consortium (1995) A gene (PHEX) with homologies to endopeptidases is mutated in patients with $\mathrm{X}$-linked hypophosphatemic rickets. Nat Genet 11(2):130-136

Imanishi Y, Hosokawa Y, Yoshimoto K, Schipani E, Mallya S et al (2001) Primary hyperparathyroidism caused by parathyroidtargeted overexpression of cyclin D1 in transgenic mice. J Clin Invest 107(9): 1093-1102

Imel EA, Hui SL, Econs MJ (2007) FGF23 concentrations vary with disease status in autosomal dominant hypophosphatemic rickets. J Bone Miner Res 22(4):520-526

Janicic N, Pausova Z, Cole DEC, Hendy GN (1995) Insertion of an Alu sequence in the $\mathrm{Ca}\left(2^{+}\right)$-sensing receptor gene in familial hypocalciuric hypercalcemia and neonatal severe hyperparathyroidism. Am J Hum Genet 56(4):880-886

Jonsson KB, Zahradnik R, Larsson T, White KE, Sugimoto $\mathrm{T}$ et al (2003) Fibroblast growth factor 23 in oncogenic osteomalacia and X-linked hypophosphatemia. N Engl J Med 348(17): $1656-1663$

Kato M, Patel MS, Levasseur R, Lobov I, Chang BH et al (2002) Cbfa1-independent decrease in osteoblast proliferation, osteopenia, and persistent embryonic eye vascularization in mice deficient in Lrp5, a Wnt coreceptor. J Cell Biol 157(2):303-314

Klaften M, Hrabě de Angelis M (2005) ARTS: a web-based tool for the set-up of high-throughput genome-wide mapping panels for the SNP genotyping of mouse mutants. Nucleic Acids Res 33(Web Server Issue):W496-W500

Klempt M, Rathkolb B, Fuchs H, Hrabé de Angelis M, Wolf E (2006) Genotype-specific environmental impact on the variance of blood values in inbred and F1 hybrid mice. Mamm Genome 17(2):93-102

Kruse K, Woelfel D, Strom TM (2001) Loss of renal phosphate wasting in a child with autosomal dominant hypophosphatemic rickets caused by a FGF23 mutation. Horm Res 55(6):305-308

Kurima K, Peters LM, Yang Y, Riazuddin S, Ahmed ZM et al (2002) Dominant and recessive deafness caused by mutations of a novel gene, TMC1, required for cochlear hair-cell function. Nat Genet 30:277-284

Langston AL, Ralston SH (2004) Management of Paget's disease of bone. Rheumatology 43(8):955-959

Lisse TS, Thiele F, Fuchs H, Hans W, Przemeck GK et al (2008) ER stress-mediated apoptosis in a new mouse model for osteogenesis imperfecta. PLoS Genet 4(2):e7

Liu X (1995) A targeted mutation at the known collagenase cleavage site in mouse type I collagen impairs tissue remodeling. J Cell Biol 130(1):227-237

Lomeli H, Ramos-Mejia V, Gertsenstein M, Lobe CG, Nagy A (2000) Targeted insertion of Cre recombinase into the TNAP gene: excision in primordial germ cells. Genesis 26(2):116-117

Lorenz-Depiereux B, Guido VE, Johnson KR, Zheng QY, Gagnon LH et al (2004) New intragenic deletions in the Phex gene clarify $\mathrm{X}$-linked hypophosphatemia-related abnormalities in mice. Mamm Genome 15(3):151-161

Lorenz-Depiereux B, Bastepe $\mathrm{M}$, Benet-Pagès A, Amyere $\mathrm{M}$, Wagenstaller $\mathrm{J}$ et al (2006a) DMP1 mutations in autosomal recessive hypophosphatemia implicate a bone matrix protein in the regulation of phosphate homeostasis. Nat Genet 38(11): $1248-1250$

Lorenz-Depiereux B, Benet-Pagès A, Eckstein G, TenenbaumRakover Y, Wagenstaller J et al (2006b) Hereditary hypophosphatemic rickets with hypercalciuria is caused by mutations in 
the sodium-phosphate cotransporter gene SLC34A3. Am J Hum Genet 78(2):193-201

Lorenz-Depiereux B, Schnabel D, Tiosano D, Häusler G, Strom TM (2010) Loss-of-function ENPP1 mutations cause both generalized arterial calcification of infancy and autosomalrecessive hypophosphatemic rickets. Am J Hum Genet 86(2): $267-272$

MacGregor GR, Zambrowicz BP, Soriano P (1995) Tissue nonspecific alkaline phosphatase is expressed in both embryonic and extraembryonic lineages during mouse embryogenesis but is not required for migration of primordial germ cells. Development 121(5): 1487-1496

Mäkitie O, Doria A, Kooh SW, Cole WG, Daneman A et al (2003) Early treatment improves growth and biochemical and radiographic outcome in X-linked hypophosphatemic rickets. J Clin Endocrinol Metab 88(8):3591-3597

Marini JC, Cabral WA, Barnes AM (2010) Null mutations in LEPRE1 and CRTAP cause severe recessive osteogenesis imperfect. Cell Tissue Res 339(1):59-70

Marklund U, Hansson E, Sundström E, Hrabě de Angelis M, Przemeck GKH et al (2010) Domain-specific control of neurogenesis achieved through patterned regulation of notch ligand expression. Development 137:437-445

Marks SC Jr, Lane PW (1976) Osteopetrosis, a new recessive skeletal mutation on chromosome 12 of the mouse. J Hered 67: $11-18$

Marx SJ, Attie MF, Levine MA, Spiegel AM, Downs RW Jr et al (1981) The hypocalciuric or benign variant of familial hypercalcemia: clinical and biochemical features in fifteen kindreds. Medicine 60(6):397-412

McGowan KA, Li JZ, Park CY, Beaudry V, Tabor HK et al (2008) Ribosomal mutations cause p53-mediated dark skin and pleiotropic effects. Nat Genet 40(8):963-970

Mejia-Gaviria N, Gil-Peña H, Coto E, Pérez-Menéndez TM, Santos F (2010) Genetic and clinical peculiarities in a new family with hereditary hypophosphatemic rickets with hypercalciuria: a case report. Orphanet J Rare Des 5:1-4

Moriyama K, Hanai A, Mekada K, Yoshiki A, Ogiwara K et al (2011) Kbus/Idr, a mutant mouse strain with skeletal abnormalities and hypophosphatemia: identification as an allele of 'Hyp'. J Biomed Sci 18:60

Mornet E, Stura E, Lia-Baldini AS, Stigbrand T, Ménez A et al (2001) Structural evidence for a functional role of human tissue nonspecific alkaline phosphatase in bone mineralization. J Biol Chem 276(33):31171-31178

Moss DW (1994) Release of membrane-bound enzymes from cells and the generation of isoforms. Clin Chim Acta 226:131-142

Nakajima K, Yamazaki K, Kimura H, Takano K, Miyoshi H et al (2009) Novel gain of function mutations of the calcium-sensing receptor in two patients with PTH-deficient hypocalcemia. Intern Med 48(22):1951-1956

Narisawa S, Fröhlander N, Millan JL (1997) Inactivation of two mouse alkaline phosphatase genes and establishment of a model of infantile hypophosphatasia. Dev Dyn 208(3):432-446

Nicklas W, Baneux P, Boot R, Decelle T, Deeny AA et al (2002) Recommendations for the health monitoring of rodent and rabbit colonies in breeding and experimental units. Lab Anim 36(1): $20-42$

Panteghini M (1991) Benign inherited hyperphosphatemia of intestinal origin: report of two cases and a brief review of the literature. Clin Chem 37(8):1449-1452

Pedrazzoni M, Alfano FS, Girasole G, Giuliani N, Fantuzzi M et al (1996) Clinical observations with a new specific assay for bone alkaline phosphatase: a cross-sectional study in osteoporotic and pagetic subjects and a longitudinal evaluation of the response to ovariectomy, estrogens, and bisphosphonates. Calcif Tissue Int 59(5):334-338

Pollak MR, Brown EM, Chou YHW, Hebert SC, Marx SJ et al (1993) Mutations in the human $\mathrm{Ca}^{2+}$-sensing receptor gene cause familial hypocalciuric hypercalcemia and neonatal severe hyperparathyroidism. Cell 75:1297-1303

Pollak MR, Chou YHW, Marx SJ, Steinmann B, Cole DEC et al (1994) Familial hypocalciuric hypercalcemia and neonatal severe hyperparathyroidism. J Clin Invest 93(3):1108-1112

Rathkolb B, Decker T, Fuchs E, Soewarto D, Fella C et al (2000) The clinical-chemical screen in the Munich ENU mouse mutagenesis project: screening for clinically relevant phenotypes. Mamm Genome 11:543-546

Rauch DA, Hurchla MA, Harding JC, Deng H, Shea LK et al (2010) The ARF tumor suppressor regulates bone remodeling and osteosarcoma development in mice. PLoS One 5(12):e15755

Rubio-Aliaga I, Soewarto D, Wagner S, Klaften M, Fuchs H et al (2007) A genetic screen for modifiers of the delta-1-dependent notch signaling function in the mouse. Genetics 175(3):1451-1463

Segawa H, Onitsuka A, Kuwahata M, Hanabusa E, Furutani J et al (2009) Type IIc sodium-dependent phosphate transporter regulates calcium metabolism. J Am Soc Nephrol 20(1):104-113

Simon-Bouy B, Taillandier A, Fauvert D, Brun-Heath I, Serre JL et al (2008) Hypophosphatasia: molecular testing of 19 prenatal cases and discussion about genetic counseling. Prenat Diagn 28(11): 993-998

Singer FR, Clemens TL, Eusebio RA, Bekker PJ (1998) Risedronate, a highly effective oral agent in the treatment of patients with severe Paget's disease. J Clin Endocrinol Metab 83(6): 1906-1910

Siraganian PA, Mulvihill JJ, Mulivor RA, Miller RW (1989) Benign familial hyperphosphatasemia. JAMA 261(9):1310-1312

Smits P, Bolton AD, Funari VM, Hong M, Boyden ED et al (2010) Lethal skeletal dysplasia in mice and humans lacking the golgin GMAP-210. N Engl J Med 362:206-216

Soewarto D, Fella C, Teubner A, Rathkolb B, Pargent W et al (2000) The large-scale Munich ENU-mouse-mutagenesis screen. Mamm Genome 11(7):507-510

Soewarto D, Klaften M, Rubio-Aliago I (2009) Features and strategies of ENU mouse mutagenesis. Curr Pharm Biotech 10:198-213

Srivastava AK, Bhattacharyya S, Li X, Mohan S, Baylink DJ (2001) Circadian and longitudinal variation of serum C-telopeptide, osteocalcin, and skeletal alkaline phosphatase in $\mathrm{C} 3 \mathrm{H} / \mathrm{HeJ}$ mice. Bone 29(4):361-367

Srivastava AK, Mohan S, Wergedahl JE, Baylink DJ (2003) A genomewide screening of $N$-ethyl- $N$-nitrosourea-mutagenized mice for musculoskeletal phenotypes. Bone 33:179-191

Strom TM, Jüppner H (2008) PHEX, FGF23, DMP1 and beyond. Curr Opin Nephrol Hypertens 17(4):357-362

Taillandier A, Cozien E, Muller F, Merrien F, Bonnin E et al (2000) Fifteen new mutations $(-195 \mathrm{C}>\mathrm{T}, \mathrm{L}-12 \mathrm{X}, 298-2 \mathrm{~A}>\mathrm{G}$, T117 N, A159T, R229S, 997+2T > A, E274X, A331T, H364R, D389G, 1256delC, R433H, N461I, C472S) in the tissue-nonspecific alkaline phosphatase (TNSALP) gene in patients with hypophosphatasia. Hum Mutat 15:292-293

Tenenhouse HS (1999) X-linked hypophosphataemia: a homologous disorder in humans and mice. Nephrol Dial Transpl 14:333-341

Tieder M, Modai D, Samuel R, Arie R, Halabe A et al (1985) Hereditary hypophosphatemic rickets with hypercalciuria. N Engl J Med 312(10):611-617

Tiosano D, Hochberg Z (2009) Hypophosphatemia: the common denominator of all rickets. J Bone Miner Metab 27(4):392-401

Wenkert D, McAlister WH, Coburn SP, Zerega JA, Ryan LM et al (2011) Hypophosphatasia: nonlethal disease despite skeletal 
presentation in utero (17 new cases and literature review). J Bone Miner Res 26(10):2389-2398

Whyte MP (2010) Physiological role of alkaline phosphatase explored in hypophosphatasia. Ann NY Acad Sci 1192(1):190-200
Xiong X, Qi X, Ge X, Gu P, Zhao J et al (2008) A novel Phex mutation with defective glycosylation causes hypophosphatemia and rickets in mice. J Biomed Sci 15(1):47-59 